\title{
ADVANCED CHARACTERIZATION OF FRACTURED RESERVOIRS IN CARBONATE ROCKS: THE MICHIGAN BASIN
}

Semi-Annual Report

October 1, 2001-March 31, 2002

By:

James R. Wood, Michigan Technological University

William B. Harrison, Western Michigan University

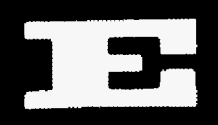

William B. Harrison, Western Michigan University

Date Published: November 2002

Work Performed Under Contract No. DE-AC26-98BC15100

Michigan Technological University

Houghton, Michigan

\section{National Energy Technology Laboratory National Petroleum Technology Office U.S. DEPARTMENT OF ENERGY Tulsa, Oklahoma}




\section{DISCLAIMER}

This report was prepared as an account of work sponsored by an agency of the United States Government. Neither the United States Government nor any agency thereof, nor any of their employees, makes any warranty, expressed or implied, or assumes any legal liability or responsibility for the accuracy, completeness, or usefulness of any information, apparatus, product, or process disclosed, or represents that its use would not infringe privately owned rights. Reference herein to any specific commercial product, process, or service by trade name, trademark, manufacturer, or otherwise does not necessarily constitute or imply its endorsement, recommendation, or favoring by the United States Government or any agency thereof. The views and opinions of authors expressed herein do not necessarily state or reflect those of the United States Government.

This report has been reproduced directly from the best available copy. 
$\mathrm{DOE} / \mathrm{BC} / 15100-3$

Distribution Category UC-122

\title{
Advanced Characterization of Fractured Reservoirs in Carbonate Rocks: The Michigan Basin
}

By

James R. Wood, Michigan Technological University, Houghton, MI William B. Harrison, Western Michigan University, Kalamazoo, MI

December 2002

Work Performed Under DE-AC26-98BC15100

\author{
Prepared for \\ U.S. Department of Energy \\ Assistant Secretary for Fossil Energy \\ Purna Halder, Project Manager \\ National Energy Technology Laboratory \\ National Petroleum Technology Office \\ One West Third Street, Suite 1400 \\ Tulsa, OK 74103
}

\author{
Prepared by \\ Michigan Technological University \\ 1400 Townsend Drive \\ Houghton, Ml 49931
}




\section{TABLE OF CONTENTS}

DISCLAIMER

ABSTRACT $\ldots \ldots \ldots \ldots \ldots \ldots \ldots \ldots \ldots \ldots \ldots \ldots \ldots$ vii

TABLE OF CONTENTS $\ldots \ldots \ldots \ldots \ldots \ldots \ldots \ldots \ldots \ldots \ldots \ldots \ldots$ iii

LIST OF GRAPHICAL MATERIALS $\ldots \ldots \ldots \ldots \ldots \ldots \ldots \ldots \ldots \ldots$ v

EXECUTIVE SUMMARY $\ldots \ldots \ldots \ldots \ldots \ldots \ldots \ldots \ldots \ldots \ldots$ ix

INTRODUCTION $\ldots \ldots \ldots \ldots \ldots \ldots \ldots \ldots \ldots \ldots \ldots \ldots \ldots \ldots$

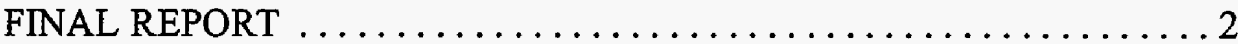

Chapter 1. Introduction - History and Background of the Michigan Basin 2

THE MICHIGAN BASIN . . . . . . . . . . . . . . . . 2

GRAVITY ANOMALY $\ldots \ldots \ldots \ldots \ldots \ldots \ldots \ldots \ldots \ldots \ldots \ldots \ldots \ldots \ldots$

BASEMENT STRUCTURE $\ldots \ldots \ldots \ldots \ldots \ldots \ldots \ldots \ldots \ldots$

SEDIMENTOLOGY ..................... 3

THE CENTRAL MICHIGAN BASIN (CMB) .......... 4

THE CMB IN THE VICINITY OF VERNON FIELD . . . . . . . 5

COMPOSITE CROSS-SECTION ACROSS MICHIGAN BASIN . 5

DISCUSSION $\ldots \ldots \ldots \ldots \ldots \ldots \ldots \ldots \ldots \ldots \ldots \ldots \ldots \ldots \ldots$

Chapter 2: Data and Databases $\ldots \ldots \ldots \ldots \ldots \ldots \ldots \ldots 6$

Chapter 3. Lineations, Faults and Fractures in the Michigan Basin . . . 6

Chapter 4. Relation of Faults and Fractures to Reservoirs ........ 8

Chapter 5. Conclusions ....................... 8

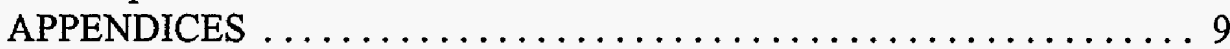

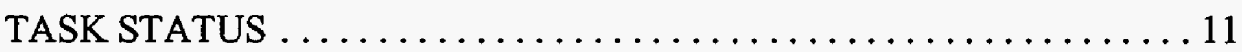

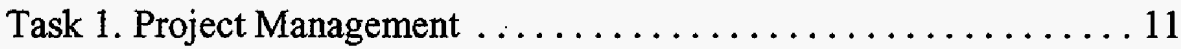

Subtask 1.1 Technical Aspects $\ldots \ldots \ldots \ldots \ldots \ldots \ldots \ldots \ldots \ldots 11$

Subtask 1.2 Financial Reports and Accounting $\ldots \ldots \ldots \ldots \ldots \ldots 11$

Task 2. Basin Analysis . . . . . . . . . . . . . . . . . 11

Subtask 2.1 Geology $\ldots \ldots \ldots \ldots \ldots \ldots \ldots \ldots \ldots \ldots \ldots \ldots$

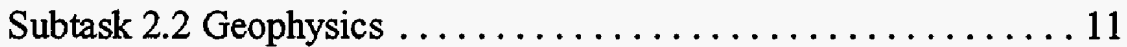

Subtask 2.3 Hydrology . . . . . . . . . . ............... . 12

Task 3. Quantification and Mapping . . . . . . . . . . . . . 13

Subtask 3.1 Data Acquisition . . . . . . . . . . . . . . . . 13

Subtask 3.3 Fracture Analysis $\ldots \ldots \ldots \ldots \ldots \ldots \ldots \ldots \ldots \ldots$

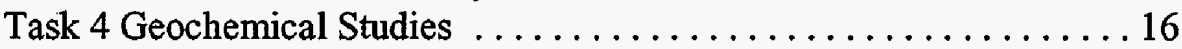

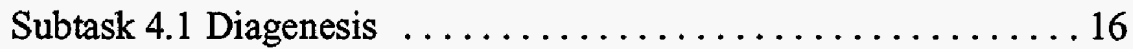

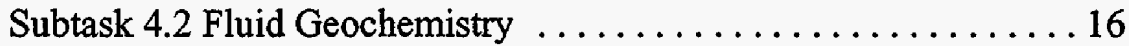

Task 5. Technology Transfer (WBH \& JRW) . . . . . . . . . 16

Subtask 5.1 Public Outreach $\ldots \ldots \ldots \ldots \ldots \ldots \ldots \ldots \ldots \ldots$

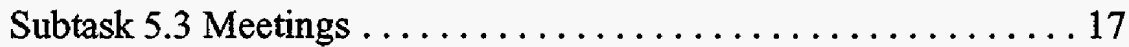

CONCLUSIONS ............................... 17

REFERENCES .............................. 19

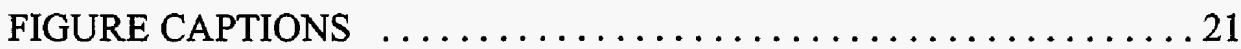

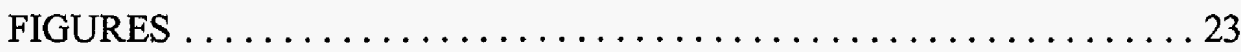

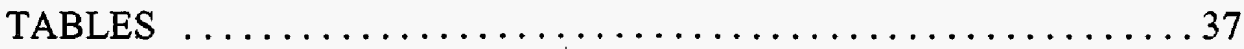





\section{LIST OF GRAPHICAL MATERIALS}

Figure 1. Bouger gravity anomaly for the State of Michigan.

Figure 2. Stratigraphic column for the State of Michigan

Figure 3. Map for Lower Michigan Peninsula showing Northwest - Southeast orientation of major lineations mapped from formation tops data.

Figure 4. Structure contour map of Top of the Dundee Formation for the Central Michigan Basin showing how the central basin is split into to sub-basins.

Figure 5. Howell Anticline Fault and Lucas-Monroe faults mapped from Dundee formation top picks.

Figure 6. Surface relief map of Michigan based on the gridded tops data for the Dundee Formation.

Figure 7. Map showing location and outline of Central Michigan Basin (CMB). Contours represent structure on top of Dundee Formation.

Figure 8. East-West and North-South cross-section across Michigan Basin. Line is calculated from grid of Dundee Formation top data. Points are top picks for Dundee Formation.

Figure 9.Cross-section across Michigan Basin in vicinity of Vernon Field. Curve represents structure on top of Dundee Formation.

Figure 10. Cross-section across Michigan Basin in vicinityof Vernon Field at latitude 43.76. Curve represents structure on top of Dundee Formation.

Figure 11. Composite cross section across Michigan Basin at latitude 43.76 for Antrim, Dundee, Salina "A" and Prairie du Chien Formations. 



\section{ABSTRACT}

This project is now in a 1-year continuation for the purpose of completing and summarizing the major results of the study.

The purpose of the study was to collect and analyze existing data on the Michigan Basin for fracture patterns on scales ranging form thin section to basin. The data acquisition phase has been successfully concluded with the compilation of several large digital databases containing nearly all the existing information on formation tops, lithology and hydrocarbon production over the entire Michigan Basin. These databases represent the cumulative result of over 80 years of drilling and exploration.

Plotting and examination of these data show that contrary to most depictions, the Michigan Basin is in fact extensively faulted and fractured, particularly in the central portion of the basin. This is in contrast to most of the existing work on the Michigan Basin, which tends to show relatively simple structure with few or minor faults. It also appears that these fracture and faults control the Paleozoic sediment deposition, the subsequent hydrocarbon traps and very likely the regional dolomitization patterns.

Recent work has revealed that a detailed fracture pattern exists in the interior of the Central Michigan Basin, which is related to the mid-continent gravity high. The inference is that early Precambrian, ( $1 \mathrm{Ga})$ rifting events presumed by many to account for the gravity anomaly subsequently controlled Paleozoic sedimentation and later hydrocarbon accumulation. There is a systematic relationship between the faults and a number of gas and oil reservoirs: major hydrocarbon accumulations consistently occur in small anticlines on the upthrown side of the faults.

The main tools used in this study to map the fault/fracture patterns are detailed, closeinterval ( $\mathrm{CI}=10$ feet) contouring of the formation top picks accompanied by a new way of visualizing the data using a special color spectrum to bring out the third dimension. In addition, recent improvements in visualization and contouring software were instrumental in the study.

Other accomplishments of this past reporting period include obtaining a complete landgrid for the State of Michigan and further processing of the high and medium resolution DEM files. We also have measured new fluid inclusion data on dolomites from several fields that suggest that the dolomitization occurred at temperatures between 100 and $150 \mathrm{C}$. Finally, we have extracted the lithologic data for about 5000 wells and are in the process of integrating this data into the overall model for the Michigan Basin. 



\section{EXECUTIVE SUMMARY}

The main objective of this project is to develop a comprehensive dataset of geologic data for the subsurface of the Michigan Basin and use this data to explain the origin and distribution of the fractured carbonate reservoirs in the Basin. The database is based on the "data cube" concept in which the Michigan Basin is divided into a 3-dimensional grid, which is then populated with appropriate attributes, such as depths of formation tops, and lithology. The basic data used was the latitude - longitude coordinates of gas and/or oil wells coordinated with the appropriate depth for the specific attribute. These data were obtained from existing digital databases supplemented with a database of raster images of the original paper reports, which for Michigan consists of driller's reports and scout tickets.

To date 7672 driller's reports ( 1 - 8 pages each) and over 17,000 scout tickets have been scanned and organized in a digital database. These are tiff files organized in subdirectories labeled by county name in a PC (e.g. Microsoft Windows) environment. A digital dataset of formation tops has also been compiled. Presently, this consists of over 700,000 top picks, of which about $50 \%$ can be considered public domain. (The rest can still be purchased from vendors.) Work is continuing to expand the public domain database.

To help organize and access the large amount of data compiled in this project, a program was written that allows a user to access all the data via a simple graphical interface. This is the ATLAS program now in version 3 and being updated to a version 4 currently. ATLAS displays the data on a State map in a variety of ways and will also export subsets of the data to MS Access file for use by other programs. A unique feature of ATLAS is that it will also access our database of raster images and allow the user to update or expand the digital database in ATLAS. This is a timesaving feature that can be used for any properly structured database.

The fracture study based on these data has been expanded in the past year from a, detailed mapping of several key fracture-dominated fields (Deep River and N. Adams), to over 2 dozen fields which appear to include all the hydrothermally altered dolomite reservoirs in the Basin. The distribution of these altered fields is discussed in this report.

As reported last time we were successful in obtaining a 3D seismic survey shot by Marathon Oil Company over Stony Point Field. We now have a large data set ( $>4 \mathrm{~Gb})$ that we are in the process of examining. Adding the Stoney Point data approximately doubles our data inventory.

The general fracture picture that is emerging in the Michigan Basin is a dominant NW $\mathrm{SE}$ trend that manifests itself on a field scale and can be mapped in outcrop. The conjugate direction, roughly, a NE - SW trend is also established in some fields. Data (mainly gravity) suggests that this trend is related to a deep basement structural trend coincident with the Michigan Basin Gravity High. This data has been interpreted as evidence for an old rifting episode early in the Proterozoic history of the Basin. The locations and geometry of 
many gas and oil fields in the central part of the Michigan Basin are consistent with this interpretation: elongated fields oriented NW - SE or SE - NW with many on the margins of the gravity high. 


\section{INTRODUCTION}

The main focus of this study is on the fracture and fault patterns in the Michigan Basin and their relation to hydrocarbon deposits. Michigan is a mature basin with abundant data that could perhaps serve as an analog for other intercratonic basins, such as the Williston and Illinois Basins.

Michigan has produced nearly a billion barrels of oil from the 1920's to the present, as much as 50\% from fractured carbonates. (Much of the rest of the production is from the Silurian pinnacle reef trend in Northern Michigan.) Michigan is a mature petroleum province now and has been extensively drilled for over 80 years. As such it provides a wealth of information in an area where companies are now inclined to release proprietary data. Consequently the two goals of this study were to (1) collect and organize this data, and (2), use it to see if any new light could be shed on the nature and origin of the fractured reservoirs.

Previously we reported that there are two types of large-scale fractures in the Michigan Basin: those associated with anticlines and those indicated by hydrothermal dolomitization. We now report that many of these fractures have been identified as faults with substantial vertical displacement. This identification is based on the tight packing of structural contours and by the presence of long, linear pods of dolomite mapped in the subsurface. In addition to the large faults mapped in the southeastern quadrant of the Michigan Basin and in the Thumb area, we have now mapped an extensive array of faults in the Central Michigan Basin. These faults are not always indicated on geologic maps of the Michigan Basin due to lack of surface exposure, but their presence can be inferred by the tight packing of contours on most any of the post-Cambrian sediments.

The fractured carbonate reservoirs selected for this study are unusual in that the main trapping mechanism is the generation of enhanced porosity caused by hydrothermal dolomitization. They are similar to reservoirs in many basins worldwide where fractured dolomites zones form important oil and gas reservoirs. Termed "dolomite chimneys", in the Michigan Basin, they have long been among the most prolific producers of hydrocarbons in the world. However, key aspects of their origin(s), distribution and architecture have been enigmatic. They have been difficult to find and once found, many have proven difficult to produce efficiently. The Michigan Basin is well suited to serve as a model for fractured reservoirs. It is a mature basin that contains almost 50,000 gas and oil wells with extensive data and rock samples. Over 150 million barrels oil has been produced from fractured carbonate reservoirs in Michigan and adjacent states. The Dundee Formation alone has produced over 350 million barrels, approximately 40-50 million from fractured, dolomitized reservoirs. It has been estimated that nearly this amount of hydrocarbons remains to be recovered.

The data from driller's reports continues to be collected and scanned and results to date are now on the Internet. Several counties are now complete and work is in progress on several others. We are working to make the software packages required to display and manipulate 
the data available as well. The software will permit visualization and interpretation on both large and small scales. The main deliverable will be a data cube for the Michigan Basin that will include:

A library of formation tops picks $(300,000+)$

digitized well locations (latitude \& longitude; 50,000+)

scanned images of well header records

digitized and interpreted logs of key wells

hydrocarbon logs,

engineering data, and key horizons picked from 2D \& 3D seismic data

a landgrid for the State of Michigan

\section{FINAL REPORT}

The final report will be a document 60-80 pages in length, exclusive of figures, and will contain an appendix that will describe the digital data on the Web site. The web site will allow access to the project data via FTP downloads. The Atlas software should also be available. In addition a library of figures with captions and all PowerPoint presentations made over the duration of the project will be available. In this report, a summary of progress for Chapter 3 will be presented.

\section{Chapter 1. Introduction - History and Background of the Michi- gan Basin}

\section{THE MICHIGAN BASIN}

The Michigan Basin is a large ( $200,000 \mathrm{~km} 2)$ ovate basin, approximately 200 mile EastWest and 300 miles North-South. It is similar to other intercratonic basins such as the Williston and Illinois Basins that are characterized by having well-defined depocenters rather than depositional axes, such the Denver and Anadarko Basins. The Michigan Basin is bounded by the Wisconsin highlands to the west, the Precambrian Algonquin, the Ordovician Kankakee and post-Silurian Findlay arches to the south and the Precambrian rocks of the Upper Peninsula to the North. The arches were all low relief and were in place by the end of the Silurian.

\section{GRAVITY ANOMALY}

A major (positive) gravity anomaly (Figure 1) runs through the center of the Michigan Basin. It is part of a larger gravity high that runs up to the Upper Peninsula, then turns and runs southwest to form the mid-continent gravity high. This is clearly a major structural feature and has been postulated to play a role in the development of the Michigan Basin. It is widely regarded as representing a "failed arm" of a transcontinental rift zone, similar in 
some respects to the present day Red Sea - East African Rift System. Very few wells have penetrated the rift zone all the way to the Precambrian; the McClure-Sparks well in Gratiot County is the only deep test in Michigan to have done so. This well penetrated the complete sedimentary section all the way to the Precambrian (Keweenawan) Red Beds.

\section{BASEMENT STRUCTURE}

The basement structure is of critical importance in the development of the Michigan Basin, including the sedimentation and subsequent folding, fracturing and faulting. It is generally thought to consist of a melange of various terrains juxtaposed and fused in the Precambrian but well control is largely lacking, particularly in the central portions of the Basin and only a few wells in total penetrate to the Precambrian, most around the periphery of the Basin. The Grenville Metamorphic Front extends from Ontario into Eastern Michigan and gneiss and schist are found in the basement rocks in Michigan east of the Grenville Front. Rocks to the west are granite and granite wash, while basement rocks to the north (in the Upper Peninsula) are quartzite. The Sparks well is the only Precambrian test on the gravity anomaly and encountered Keweenawan red beds.

\section{SEDIMENTOLOGY}

The stratigraphic section for the State of Michigan extends from the late Precambrian to late Jurassic (Figure 2). The sedimentary record can be divided into three main stages, clastics, chemical sediments including carbonates and evaporites, and back to fine-grained clastics. All stages are Paleozoic. Stage 1 is dominated by clastic sedimentation, mainly sandstones, that begins into the Early Cambrian with the Jacobsville Sandstone, and ends in the Early Ordovician with the St. Peter Sandstone. Stage 2 is marked by the deposition of a thick section of chemical sediments, beginning with carbonates in the Early-to-Middle Ordovician Trenton-Black River, proceeding through the Silurian Evaporites and ending with the Late Devonian Squaw Bay Limestone. The Late Devonian Antrim Shale signals the beginning of the clastic-dominated $3^{\text {rd }}$ stage that ends in the Late Jurassic with the Red Beds on top of the Late Pennsylvanian Grand River Formation. The cycle is clastics to chemical sediments (evaporites) back to clastics. Summing the maximum thickness for all formations yields about 18000 feet for the aggregate thickness of sedimentary fill in the Michigan Basin, a value that agrees with the aggregate thickness found in the State's deepest well, the McClure-Sparks in Gratiot County. The McClure-Sparks penetrates the entire section from Jurassic to Precambrian.

One of the most striking characteristics of the Michigan Basin sedimentation is the large volume of chemical sediments (carbonates, sulfates and salts) relative to clastic materials (sandstones and shales). The Salina (Middle Silurian) and the Detroit River Early Devonian Formations are the principal times of salt deposition in which over 3150 feet of salts were deposited in the Salina and over 1450 feet in the Detroit River. If the maximum thickness of all chemical sediments (carbonates, sulfates and chlorides) is compared to the 
aggregate maximum thickness of all the sandstones and shales, the ratio is about 10:1, chemical sediments to clastics.

\section{THE CENTRAL MICHIGAN BASIN (CMB)}

The Michigan Basin contains a number of sub-basins, most of them located in the approximate center of the Lower Michigan Peninsula (Figure 7). The deeper portions of the Michigan Basin contain a numerous depressions of various sizes, cascading down from very large, significant structures to minor depressions. Because of the relative complexity of these smaller basins and because details are lost when viewed with the entire basin, it is convenient to isolate the major sub-basin. Examination of structure contour maps for welldefined horizons such as the Dundee Formation show that central Michigan contains most of these sub-basins within an area that itself defines a larger sub-basin. This region is contained within the -2600 foot (subsea) contour on the top of the Dundee Formation and hence that contour is used here to define the Central Michigan Basin (Figure 7). It is termed here the "Central Michigan Basin" and covers most of four counties (Isabella, Clare, Midland and Gladwin) and parts of seven others.

The Central Michigan Basin (CMB) is roughly elliptical in shape and is centered at approximately the common corner of Isabella, Clare, Midland and Gladwin counties. It contains some of the most prolific producing fields in Michigan and is structurally the most complex portion of the Basin. The major axis of the Basin (as defined by the -2600 ft. Dundee contour) trends NW - SE, about 34 degrees west. Within the CMB, two major depressions are present, which appear to be major synclines separated by a major plunging anticline. The axes of these structures roughly parallel the major axis of the CMB, but not exactly. They are offset by about 25 degrees to the east.

East-West and North-South cross sections parallel to the major and minor axes of the CMB show the major features of the structures (Figure 8). These cross sections cover the entire Michigan Basin in Michigan and are rather unique. They were constructed by taking the formation tops data for the Dundee Formation, separating the data into strips parallel to the axes and plotting them as subsea depth versus distance along the relevant axis. The full line is calculated from the gridded formation tops data while the symbols represent the actual data. The line is a mathematical construct with zero width while the symbols represent all data lying in a strip of half-width about 1200 feet on either side of the calculated line.

In general, these cross sections show a shallow synclinal structure with gentle dips leading to a broad floor characterized by smaller scale structures, (synforms and antiforms). Based on these sections, the basin can be described as a simple bowl with small-scale "bumps" distributed at more or less regular intervals. If the basin is regarded as a half-wave sine function, then the "bumps" can be regarded as smaller waveforms superimposed on the half wave. The crests of these smaller waves are often gas and oil reservoirs, as reflected in the larger number of data points in their vicinity. 


\section{THE CMB IN THE VICINITY OF VERNON FIELD}

Vernon Field is a small field in the heart of the CMB that has produced about 5 million barrels of oil from the Dundee Formation. It is a useful point of reference when discussing the smaller scale structures in the CMB. Figure 9 is a cross section across the CMB at nearly 90 degrees to the structural trend defined by the large anticlines and synclines in the $\mathrm{CMB}$ and passes through the center of Vernon Field. This section is more asymmetrical compared to the whole basin. It dips gently entering the basin on the southwest but the dips are significantly steeper rising out of the basin to the northeast. In between, a number of smaller structures are present, one of which is Vernon Field. Figure 10 is an East-West cross-section through Vernon Field. Again it shows the finer details of the structure in the CMB.

\section{COMPOSITE CROSS-SECTION ACROSS MICHIGAN BASIN}

Figure 11 is a composite cross-section across the Michigan Basin showing four horizons. It was constructed by gridding the formation tops data for four formations and using commercial software (e.g. Surfer 8, () Golden Software, Inc.) to slice cross-sections at selected locations. The lines shown in Figure 11 are all calculated from the grid for each of the listed formations. (Actual data points will be added in a subsequent report.)

In general, this cross-section shows several interesting features of the Michigan Basin. One is that the more complex geometries discussed earlier based on the Dundee Formation data persist upward into the Antrim Shale (L. Devonian), but the case is not so convincing for deeper formations. The Salina "A" Formation (Silurian) top lacks much of the fine-scale detail that characterizes the Dundee and Antrim Formations but does follow the general trend established by the shallower horizons. The Prairie du Chien Formation (Ordovician) (PDC) lies about 1000 feet below the Salina "A", but shows similar detail to the Salina. The loss of fine structure is in part due to the much fewer well penetrations reaching these formations, although we cannot be sure that the fine structure is present but just not detected by this technique.

Future work will focus on construction of more cross-sections of this type with more formations. We hope to remove some of the doubt concerning the persistence of the fine structure deeper into the basin as well superimpose the actual well top data onto the plots. Superposition of the data is important not just from reassuring people that the calculated curves are accurate representations of the subsurface, but also in delineating areas where fine structure at higher levels might persist to deeper levels. This could lay the foundation for deeper plays in the Michigan Basin. 


\section{DISCUSSION}

The region defined here as the Central Michigan Basin appears to be a useful subdivision of the Michigan Basin. The CMB contains structures that do not extend beyond its boundaries and seems to have served as a persistent structural element from early in the history of the Michigan Basin up to at least the Late Devonian. It has contained the depocenters of almost every formation deposited in the Basin throughout the Paleozoic and has accumulated significantly thicker sediments that the surrounding areas. In addition, one could argue that there is a significant slope break at or near the boundary of the CMB, with steeper dips leading into the CMB.

\section{Chapter 2: Data and Databases}

One of the major tasks of this project was to obtain a comprehensive database of the Michigan subsurface. To that end we have compiled over 500,000 top picks covering 50+ horizons (Formations and marker beds) over the entire basin. To date, over 53,000 wells have been drilled in Michigan for gas and oil and most of these report anywhere from 1 or 2 to as many as $20+$ formation tops. These data were originally compiled in "driller's reports" and scout tickets, typewritten data that covers the years 1922 to the present. The challenge was to obtain these documents and then extract the data in a digital form. We have largely accomplished that task and can now turn to the second major task of this proposal, analyzing and interpreting the data.

Although a number of databases were constructed for this project, the relevant data can all be summarized in a single table that contains the surface location and the subsurface elevations for all formations. This table contains 640,000 records, each corresponding to a single top pick. Dividing by about 30 major mappable horizons, this gives an average of about 10,000 data points for each major horizon. Table 2 summarizes the data by formation and actual data count. Most of the following discussion is based on various plots and displays of these data. However it should be mentioned that work is still proceeding to correct the data since it appears that a significant number $(\sim 10 \%$ ?) of the recorded entries were in error, either from the original data sheets or during transcription. As a result, the maps displayed in this report may undergo further correction and revision with time. However, it is thought that the bulk of the data, probably $95+\%$, is now essentially correct.

\section{Chapter 3. Lineations, Faults and Fractures in the Michigan Basin}

The thick blanket of glacial drift deposits has prevented detailed mapping of the bedrock geology of the Michigan Basin from outcrop. Almost all the data available for reconstruction of the State geologic map is derived from subsurface data, which is fortunately available in abundance. Unfortunately, the nature of the data is such that it is difficult to map linear features such as faults and fractures, particularly over long distances. The result is that only a few faults are ever displayed on basin-scale maps of the Michigan Basin. Most workers in the Basin would agree that the Howell Anticline and the associated LucasMonroe structures in the Southeast corner of the Basin are well-defined features. Almost no other basin-wide faults have been consistently recognized. 
However, plots of the formation tops data, particularly the Dundee Formation, reveal a number of generally Northwest-Southeast trending lineations that can be interpreted as normal faults (Figure 3). They are basin-scale in length (10s of kilometers) and occur both near the basin depocenters and on the basin margins. These appear to be previously unmapped faults. The lineations are well defined in formations ranging from the Upper Devonian Dundee Formation to the Late Mississippian Marshall. Formations older than the Detroit River (Middle Devonian) have relatively few penetrations in the basin center. There is some doubt that the faults penetrate to the basement at all, but the interpretation favored here is that they do. Detailed mapping of formation tops also reveals the presence two interior sub-basins and as well as two well-developed anticlines to the Northeast and a set to the Southwest and a number of smaller anticlines aligned along definite trend lines (Figure 4). The term "lineation" will be used to describe the features when we do not wish to assign an interpretation (e.g. fault). We feel that the lineations in most cases do in fact represent faults, although displacements, particularly strike-slip, are difficult to document.

High-resolution contour or surface relief maps (SRMs) were used to map structural trends (Figure 6) using the formation tops data. By trial and error it was determined that adequate results could be obtained by plotting the data for the entire state on a $1000 \times 1000$ grid (e.g. approximately 200 miles in both East-West and North-South directions or about 0.2 mile (1000 feet) node-to-node). However, the best results were obtained by from a $3000 \mathrm{x}$ 3000 grid (approximate spacing of 330 feet node-to-node) which turns out to be nearly the same as 2.5-acre spacing. In Michigan, most development is on 10-acre or greater spacing, so that a grid equivalent to 2.5 -acre spacing is about the optimal grid spacing. We conclude that a $3000 \times 3000$ point grid is the optimal spacing when the data set is taken over the entire Lower Peninsula of Michigan. Most previous maps of the Michigan subsurface do not approach this level of resolution, which appears to be one reason these relatively large faults reported here remained unnoticed until now.

The basic steps involved in manipulating the top pick data are:

obtain a digital file of formation top picks with surface coordinates in latitude and longitude,

edit for errors in both well location and formation top depth

create a $1000 \times 1000$ grid over the entire State

plot closely spaced contours (5-10 foot contour intervals) and shaded relief maps to highlight further bad data

edit the dataset and eliminate the bad picks, re-grid the data on a $3000 \times 3000$ node grid again plot closely spaced contours and shaded relief maps

use the shaded relief map to pick the faults (lineations)

digitize the faults 
The (Late Devonian) Dundee Formation (a.k.a. the 302DNDE in Michigan lexicon) is a particularly useful formation when it comes to mapping subsurface lineations. For one thing, a large number of wells over the entire state penetrate this horizon, and it is a relatively unambiguous pick. Also, once the lineations are mapped for this horizon, the same traces can be superimposed on both lower and higher formations with a high degree of accuracy. Consequently, we use the Dundee as the master horizon and map a primary set of lineations on this horizon. We then document changes in lineations from this datum for other horizons (formations).

Using these techniques we can identify $13-15$ prominent lineations in the Michigan Basin. They are for the most part all northwest - southeast trending and are sub-parallel to one another (Figure 3).

\section{Chapter 4. Relation of Faults and Fractures to Reservoirs}

The basin-scale faults described here are closely related to many gas and oil deposits in the Michigan Basin. A number of highly productive fields, usually shallow anticlines, lie close to the upthrown edge of the faults and tend to parallel the fault trace. It is likely that there is a causal relationship between the faults and the traps. Although there is no evidence for strike-slip (lateral) movement, the vertical movement on many faults exceed 300 feet and the stresses involved could have deformed the nearby strata enough to produce mild anticlinal folds. The association between faults and traps would appear to be sufficient to warrant examining the undrilled segments of the faults for the presence of hydrocarbons.

\section{Chapter 5. Conclusions}

The principal conclusions of this study are that the Michigan Basin is cut by numerous (12+) major faults lying below the glacial drift and below the topmost Jurassic sediments. The faults generally trend Northwest - Southeast. These faults ("lineations") are dominant features of the subsurface topography and are well documented from at least the Late Devonian (Dundee time) to the Mississippian. These faults carve out large depressions in the Central Michigan Basin and appear to be responsible for shallow anticlines that hold or held a significant portion of the hydrocarbons in the Michigan Basin.

An obvious question is "What is the origin of these large-scale faults?". One explanation, and perhaps the simplest, is that they are expression of deep-seated normal basement faults rooted in the Precambrian rift sequence. This explanation has been invoked for the Howell Anticline Fault and the Lucas-Monroe Faults to the South - Southeast of the Central Basin (Figure 5) and it seems natural to extend it to the Central Basin itself. In this model a typical horst-graben environment, similar to the U. S. Basin and Range or the East African Rift, is envisioned for the Michigan Precambrian, with later sediments draped over preexisting faults followed by relatively minor vertical movements during the Paleozoic. 


\section{APPENDICES}




\section{TASK STATUS}

\section{Task 1. Project Management}

\section{Subtask 1.1 Technical Aspects}

Project management continues to operate smoothly: links have been established between the main Michigan Techoperations site and the sites in Kalamazoo, Traverse City and Tampa FL. Two face-to-face meetings with all personnel were held, one meeting in Traverse City, and one in Tampa. All senior team members (Wood, Harrison, Luo, Chittick) attended the spring AAPG meeting in Denver in 2001 and will attend the Houston meeting in 2002.

We are now in the process of wrapping up this project, which has been extended to end in October 2002. We are checking the task list and making sure all goals either have been reached or can be reached in time. So far, everything appears to be on schedule.

\section{Subtask 1.2 Financial Reports and Accounting}

Project expenditures are proceeding according to plan. All necessary reports have been filed with DOE Pittsburgh.

\section{Task 2. Basin Analysis}

\section{Subtask 2.1 Geology}

\section{Lineation Analysis}

The DEM data has been successfully integrated into the project and is now bearing results. Most of the technical problems have been resolved to the extend possible. It appears that the $71 / 2$ minute quadrangles with obvious noise has been traced to a bad conversion from the DEM format to the SDTS format by a USGS contractor. The USGS is aware of the problem and is moving to correct the files. It does not appear to be a problem that we can fix, or one that the USGS will have fixed in time for the high resolution data to be used in this project. However, it may be possible to purchase good files from vendors at a reasonable price. We are currently looking into that possibility.

\section{Subtask 2.2 Geophysics}

\subsubsection{Seismic}

The 3D seismic data package over Stoney Point field arrived from Marathon Oil Company in December and has been loaded onto MTU computers. Work is in progress to register the data and display it on our hardware. One Ph.D student is employed full-time on this project as part of his thesis. Although the data was received late in the project we plan to 
make as much use of it as possible in the remaining time. One goal is to image the reservoir zone at Stoney Point with the aim of relating it to fracture patterns.

Three 2D seismic lines were obtained from Marathon Oil Company near the Crystal Field in Montcalm county (MOC), loaded into GeoQuest and processed in an attempt to elucidate Dundee structure. The seismic data was shot targeting deeper plays and thus has low fold and offset to adequately resolve shallower plays such as the Dundee. From structure maps, isopach maps and initial production bubble plots, it is apparent that the Dundee of the Crystal field was faulted and probably karstified. The low fold and offset coupled with unknown static conditions creates a condition of low signal to noise ratio, making it difficult to resolve the shallow structure and fractured nature of the Dundee in the Crystal field (T. Bulloch, 1999). Bay Geophysical of Traverse City, Michigan has however, indicated that they have exclusive processing techniques, which may be able to resolve shallow low fold structure. This project will attempt to acquire data processed by Bay Geophysical, which resolves shallow structure with $2 \mathrm{D}$ data.

\subsubsection{Borehole}

The use of borehole data in this project is continuing, mostly at Western Michigan University.

\section{Subtask 2.3 Hydrology}

This task has started with the analysis of the main hydrologic units in the Michigan Basin, the basement configuration, the Traverse and Dundee Formations. Work is continuing on this subtask.

\subsubsection{Fluid Pathways}

This task is proceeding in tandem with the basin model. It has much the same problems as the mapping of the Top of Porosity in that it is necessary to read each driller's report for mention of hydrocarbon shows.

\subsubsection{Flow Model}

\subsubsection{Gas and Oil Trapping}

The show data discussed in 2.3.1 above should point toward known gas and oil fields. Thus the trapping mechanisms may be elucidated as well since we would anticipate that the shows would terminate at seals, which are generally shales, tight limestone or salt in the Michigan Basin. We will plot the oil and gas shows along with producing oil plays in a three dimensional display to show migration routes and oil and gas trapping mechanisms. 


\section{Task 3. Quantification and Mapping}

This task is approaching completion. Nearly one hundred fields in the Michigan Basin were studied as part of this project (Table 1). Well locations and formation top data were collected in paper records, scanned into images (tiff raster images), and the translated by hand into digital form. In addition, header information on each well (latitude, longitude, permit number, Kelly bushing, driller, operator, etc.) was assembled in digital format and input into a (MS Access) database. These fields cover virtually the entire Michigan Basin and account for over $90 \%$ of the total cumulative production in the State from inception of drilling $(\sim 1920)$ to present. For the most part, these fields are described in the two-volume reference set published by the Michigan Basin Geological Society.

\section{Subtask 3.1 Data Acquisition}

\section{Data Cleanup and Digitization}

This task is now competed except for scanning the driller's reports, which is on going. Over 17,000 scout tickets have been digitized as TIF images and added to the Atlas database. These are all of our currently available scout tickets. We have begun work digitizing driller's reports as multiple page TIF images. Digital well logs are being acquired from oil and gas company donations and in house digitizing. Recently, over new 5,400 wells were added to our database, bringing the total number of well locations to approximately 54,000 .

Acquisition and digitization of formation top data for the Michigan Basin is essentially complete. Three digital databases, one commercial, one State of Michigan and one from this project, have been examined as well as paper datasheets at Michigan Tech and Western Michigan Universities for subsurface data. Three types of data have been extracted: formation top picks, well headers (including geographical location) and production/lithology data.

\section{Well Headers}

This category includes all relevant information about an individual well: name, location, operator, dates spudded, drilled, and completed, fluids produced, fluid intervals, and so on. In general, these data are the beginning for all subsequent analysis as it containing the surface and bottom hole locations as well as the elevation datum (usually the Kelly bushing). For Michigan in 2000, there are over 53,000 well, gas, oil, disposal and other, in the State.

\section{Formation Top Picks}

This type of data is by far the most valuable in reconstructing the subsurface, and accordingly, more attention has been paid to gathering and verifying it. The three databases yielded nearly 900,000 ( 880,386 to be exact) top picks for over 140 formations in the Michigan Basin (Table 2). Of these, 243,546 were duplicates leaving 636,880 separate top picks. 


\section{$\underline{\text { Some Statistics }}$}

The character of this dataset can be appreciated by looking at some statistics. Although there are 146 separate formation names included in the databases, only 12 account for $50 \%$ of the picks and 50 account for $99 \%$ of the picks (Table 2). In addition, some formation names refer to the same top, but were spelled or indicated differently in the different databases. For example, the Aangstom database refers to the Salina "D" Horizon as the "Salina D Evaporite/Salt" while the State of Michigan refers to it as the "Salina D Unit". In addition, some names are obsolete and have been superseded. When these issues are resolved, the total number of units in the Basin shrinks to around 75, of which 50 or less are important on a basin-wide scale.

\section{Quality Control}

The issue of quality control is important as it relates to the accuracy, absolute and relative, of the top ticks. Generally, the smallest unit of measurement is 1 foot, so in an ideal situation, all top picks would be accurate to within 12 inches. The relative accuracy is the depth reported by the driller to each horizon and refers to each separate top pick in one well. The absolute accuracy is the subsea depth which permits comparison of one well top pick to another and is dependent on both the relative accuracy and the accuracy to which the surface elevation was measured.

Errors are also introduced when measurements are recorded or transcribed. This is not uncommon when dealing with databases this large compiled over decades by different personnel. A common error is to transpose two numbers. The only recourse here is to reexamine the original documents (driller's reports) and hope they do not contain the same error. Finally, errors are introduced when different methods are used to pick a top. For example, the logger at the well site will make picks based on the cutting brought up and later the logger will make picks based on logs. In many cases, the type of log used will make a difference in the pick, sometimes by 10 s of feet.

During this reporting period, a student reviewed all the available data for the Dundee Formation (e.g. top picks) by examining large-scale contour plots and then checking any wells that produced "bulls eyes" in the plot with the paper records. In this way he located a number of errors in the database and corrected them and reduced the occurrence of "bulls eyes" to practically zero for the Dundee Formation by correcting about 1500 wells (out of nearly 25,000). We now believe we have the best set to top picks for this important horizon. However, we also now believe that the rest of datasets likely contains similar erroneous data that will have to be similarly corrected. Given the large amount of data (see above) it is clearly a task that is unfortunately beyond the scope of this project. While we will be able to deliver a large number of public domain data on formation tops in the Michigan Basin, we will have to cite the experience with the Dundee formation and caution the user that errors still exist in the database. 


\subsubsection{Gridding}

The $7 \frac{1}{2}$ minute DEM grid for the entire State of Michigan has been completed.Work is now focussed on upgrading the individual data elements and plotting the large-scale maps.

\subsubsection{Database Management}

All data associated with this project to date has been placed into an MS Access database as promised. In addition, all documents related to the project (reports, software, etc.) have also been placed in a digital database that consists of the MS Windows normal file structure. The database can be accessed using Atlas.

Subtask 3.2 Mapping and Visualization

\subsubsection{D Mapping}

This task is now completed with regard to the surface grid. This includes cultural data, as well as hydrologic. Attention is now focussed on mapping the key subsurface horizons now that the database containing the formation tops is available.

As reported last time, basin wide mapping has begun with all Michigan well locations and formation tops input into ArcView. However we now prefer to use Golden Software Surfer (C) program for contouring because it is easier to use and it provides superior results. Part of the reason for Surfer's superiority is the number of gridding algorithms it offers together with a higher degree of user control. However, the main reason is that it can be used in tandem with ATLAS to automatically generate contour plots. As we now have over 100 fields to analyze, automating the plotting save time and dollars and permits changes and refinements that would otherwise not be possible.

\subsubsection{D Mapping}

The 3D code for displaying the gridded data described in 3.1.2 above is also finished and has been incorporated into the project software library. The code has been written in Visual Basic (VB) and preliminary plots are being generated.

\subsubsection{Reports and Maps}

Michigan Atlas - In addition to the DEM data described above, most of the progress for this reporting period has come in the development of the Atlas software. This program is turning out to be a very effective tool for consolidating and displaying the project results. We have begun to release the program to a few selected operators in the Michigan Basin for evaluation and feedback. Atlas can be used effectively to determine if certain data exists for a specific well or a group of wells. Well locations are color-coded indicating which wells have the user-requested data. 


\section{Subtask 3.3 Fracture Analysis}

Literature data has been compiled on outcrop fractures in the Michigan Basin. Samples for petrographic examination have been collected and are being prepared for petrographic examination. These data will be digitized and plotted.

\section{Task 4 Geochemical Studies}

\section{Subtask 4.1 Diagenesis}

We now have retrieved diagenetic data for the entire central Michigan Basin (Table 1). These data were retrieved from the database of scanned driller's reports, using the program Atlas 3.0. We took reported "Top of porosity" data indicating diagenetic dolomite and plotted the distribution in the Basin.

\section{Subtask 4.2 Fluid Geochemistry}

A database on subsurface fluid chemistry is being compiled for the Michigan Basin as part of a student project. Results will be presented in the annual report. Fluid analyses will be correlated with position in the Basin and plotted according to the formation of origin to see if any significant trends or correlations are present.

Subtask 4.3 Hydrocarbons

2D and 3D maps showing the distribution of hydrocarbons in the Basin are being prepared.

\section{Task 5. Technology Transfer (WBH \& JRW)}

\section{Subtask 5.1 Public Outreach}

\subsubsection{Internet (WWW)}

A new Internet site for this project has been constructed on the Michigan Tech server. Additional information and reports continue to be placed on this site and the site at Western Michigan.

\subsubsection{Newsletter}

The newsletter has been incorporated into the Web site to make it more readily available and to ease distribution problems and costs.

Subtask 5.2 Workshops (WBH) 
The PTTC workshop reported to being organized by Harrison and Wood, and held in Mt. Pleasant last spring, was rescheduled for the Fall Eastern Section AAPG meeting in

Kalamazoo. This was a better format and reached more interested parties. Plans to distribute a project DVD ROM are being considered.

\section{Subtask 5.3 Meetings}

\subsubsection{DOE Contractor Meetings}

None scheduled

\subsubsection{National and Regional Meetings}

Project personnel attended the annual AAPG meeting in Denver, CO in June 2001 and 1 paper was presented.

Project personnel also attended the annual AAPG meeting in Houston, TX in March 2002.

Project personnel also attended and participated in the Eastern Section AAPG meeting in September 2001 in Kalamazoo, MI. Harrison was one of the convenors and scheduled a section devoted to the Dundee Formation in Michigan. Results from this study were presented there. (Also at the included workshop, see above.)

\section{CONCLUSIONS}

This is the last report before the final report and the overall status of the project is good. Several projects have produced results that exceed original expectations, notably the DEM task, the databases and the visualization. The fracture study is on track but needs to be pulled together. To achieve this, two meetings, one in June and another in September have been scheduled to bring the team together in a neutral site to focus on the final report. The overall project is still on schedule and is still meeting all major goals. However attention has to be directed toward the geochemical and hydrology goals.

The Atlas program has emerged as a particularly strong contribution from the project and efforts will be made to publicize and distribute it along with the project databases. The DEM data and lineation models have also drawn interest from industry both from the approach and results points of view. We will continue to work on these aspects even after the termination of the project since they have potential to continue to grow. At present the Atlas program does not incorporate the DEM data, but that is technically possible if a suitable display medium can be found. Efforts to write code to do this have been marginally successful but so far are not up to acceptable standards. Work will continue on code development. 
The acquisition of a landgrid for Michigan has greatly contributed to the essentially completed the data cube for the Michigan Basin. The landgrid allows data from the project's digital database to be presented in the standard industry practice of maps keyed to the section-township-range system. Conversion of the landgrid for the entire state of Michigan to latitude-longitude put it in the same units as the rest of the database. It should also be possible to add capability to Atlas that will convert footage calls to lat-long coordinates and visa versa.

Sufficient digital data has been collected to begin analysis of basin scale. In the next period we expect to have structure contour maps completed for all the key horizons in the Michigan Basin. The work done on the Dundee Formation shows "stacked" contours indicative of large-scale faults. We will see if these patterns are present in formations above and/or below the Dundee.

Work is still continuing on mapping the Top of Porosity in the Basin, as well as data for hydrocarbon shows. This is time-consuming since the data have to be read off the driller's reports or scout tickets. Scanning the images and incorporating them into the Atlas program has greatly facilitated this work. 


\section{REFERENCES}

"Oil and Gas Fields of the Michigan Basin" 1968, Vol. 1, Michigan Basin Geological Society, M. S. Wollensak, Ed., Department of Geological Sciences, Michigan State University, E. Lansing, MI.

"Oil and Gas Fields of the Michigan Basin" 1968, Vol. 2, Michigan Basin Geological Society, M. S. Wollensak, Ed., Department of Geological Sciences, Michigan State University, E. Lansing, MI.

Bulloch, T., The Investigation of Fluid Properties and Seismic Attributes for Reservoir Characterization: M.S. thesis, Michigan Technological University, Houghton, Michigan, $113 p$. 


\section{FIGURE CAPTIONS}

Figure 1. Bouger gravity anomaly for the State of Michigan.

Figure 2. Stratigraphic column for the central Michigan Basin showing location of Dundee Formation (Middle Devonian).

Figure 3. Map for Lower Michigan Peninsula showing Northwest - Southeast orientation of major lineations mapped from formation tops data.

Figure 4. Structure contour map of Top of the Dundee Formation for the Central Michigan Basin showing how the central basin is split into to sub-basins.

Figure 5. Howell Anticline Fault and Lucas-Monroe faults mapper from Dundee formation top picks.

Figure 6. Surface relief map of Michigan based on the gridded tops data for the Dundee Formation.

Figure 7. Map showing location and outline of Central Michigan Basin (CMB). Contours represent structure on top of Dundee Formation.

Figure 8. East-West and North-South cross-section across Michigan Basin. Line is calculated from grid of Dundee Formation top data. Points are top picks for Dundee Formation.

Figure 9. Cross-section across Michigan Basin in vicinityof Vernon Field. Curve represents structure on top of Dundee Formation.

Figure 10. Cross-section across Michigan Basin in vicinityof Vernon Field at latitude 43.76. Curve represents structure on top of Dundee Formation.

Figure 11. Composite cross section across Michigan Basin at latitude 43.76 for Antrim, Dundee, Salina "A" and Prairie du Chien Formations. 


\section{FIGURES}




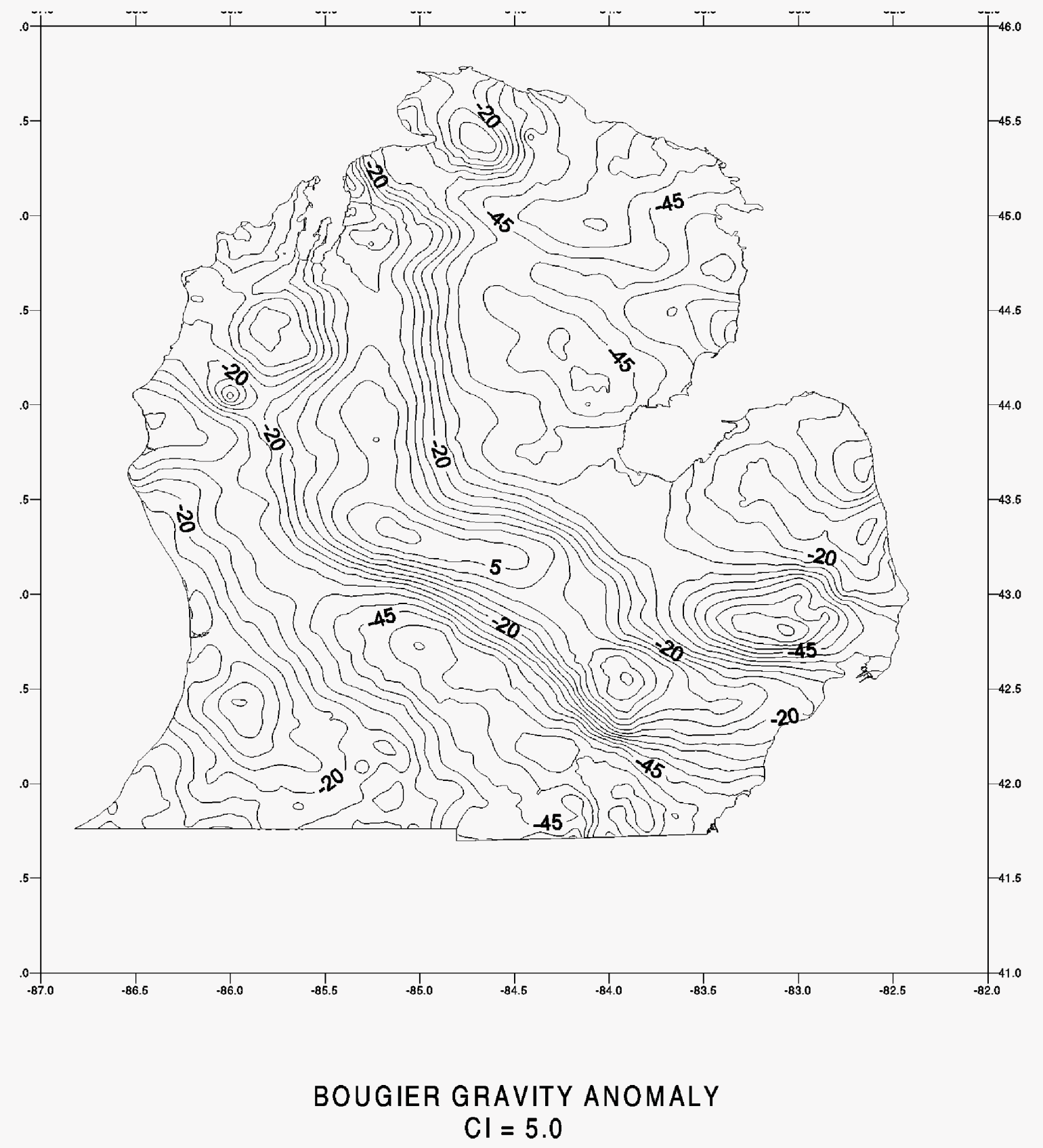

Figure 1. Bouger gravity anomaly for the State of Michigan. 


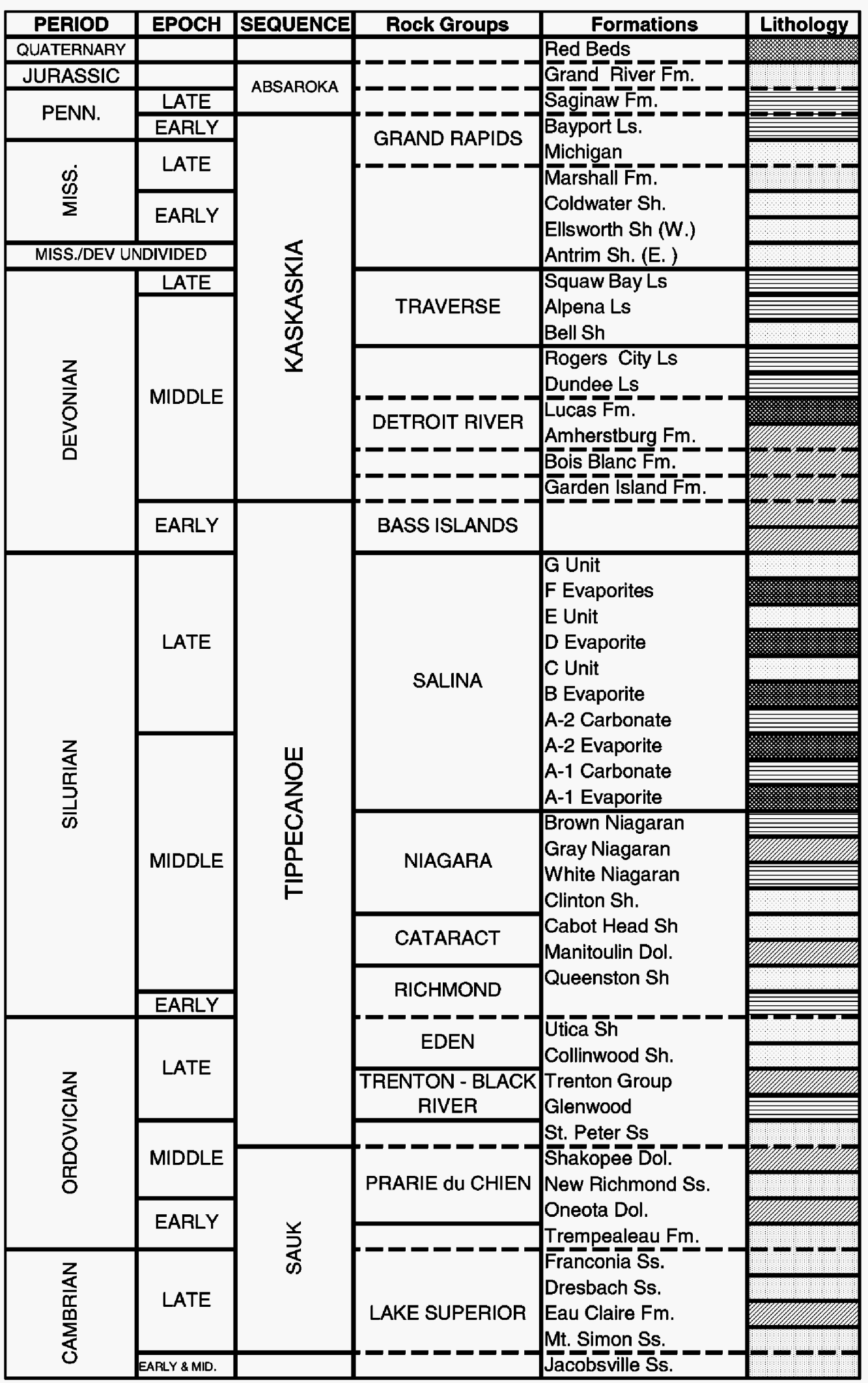

Figure 2. Stratigraphic column for central Michigan Basin showing location of Dundee Formation (Middle Devonian) 


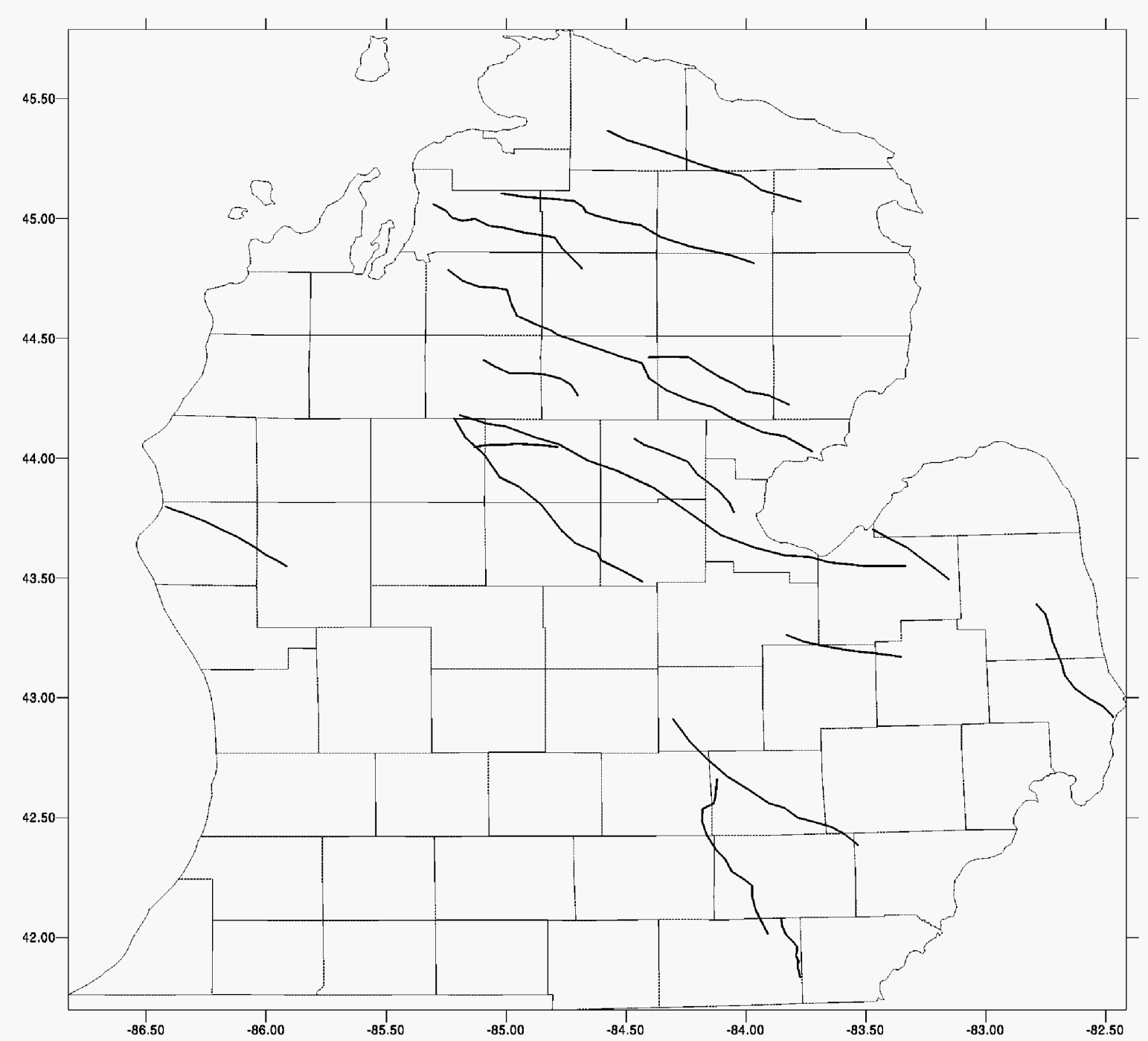

MICHIGAN BASIN LINEATION MAP FAULT MAP BASED ON 302DNDE

Figure 3. Map for Lower Michigan Peninsula showing Northwest - Southeast orientation of major lineations mapped from formation tops data. 


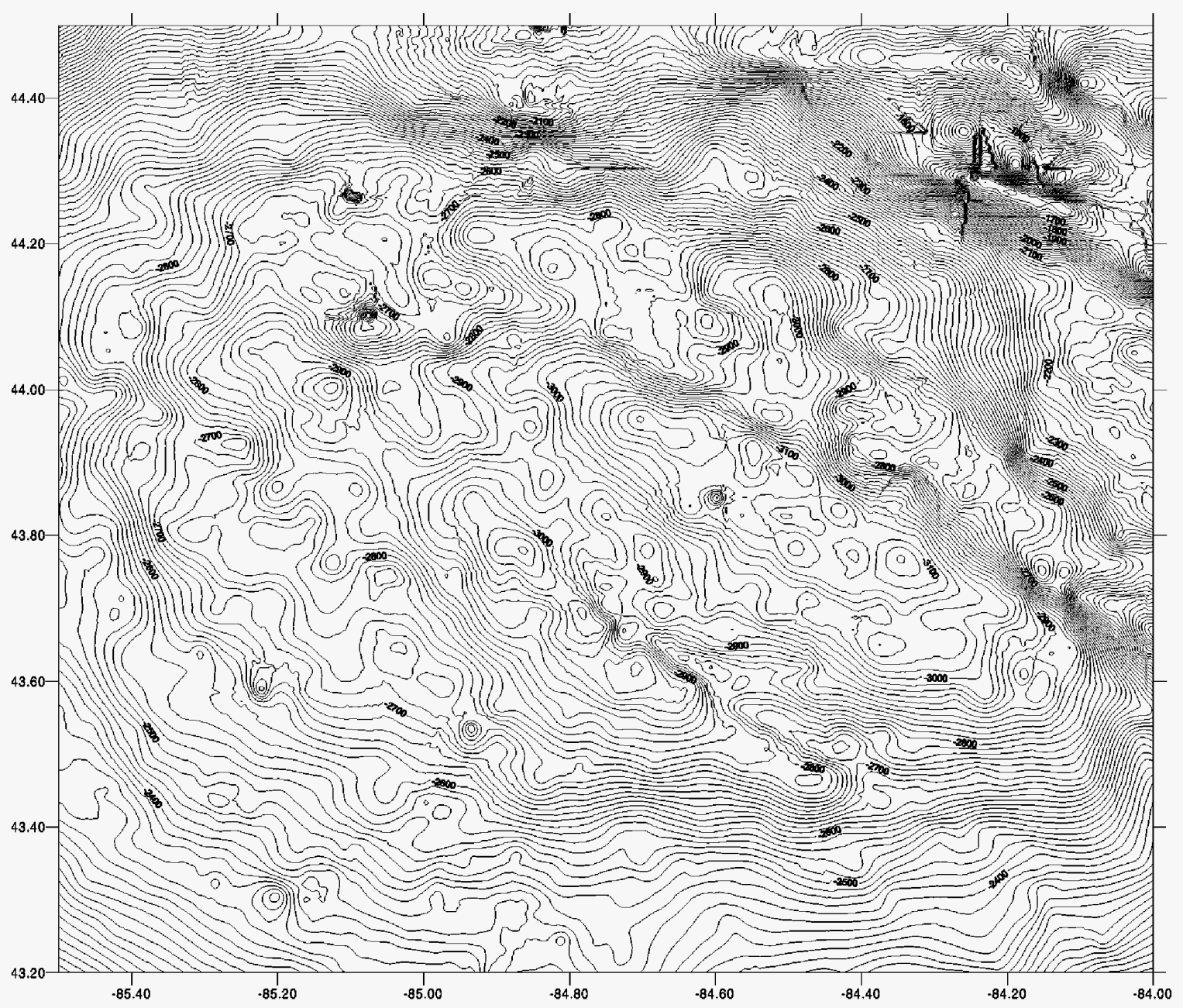

STRUCTURE MAP

TOP OF DUNDEE FORMATION

$\mathrm{Cl}=10 \mathrm{FT}$.

Figure 4. Structure contour map of Top of the Dundee Formation for the Central Michigan Basin showing how the central basin is split into to sub-basins. 


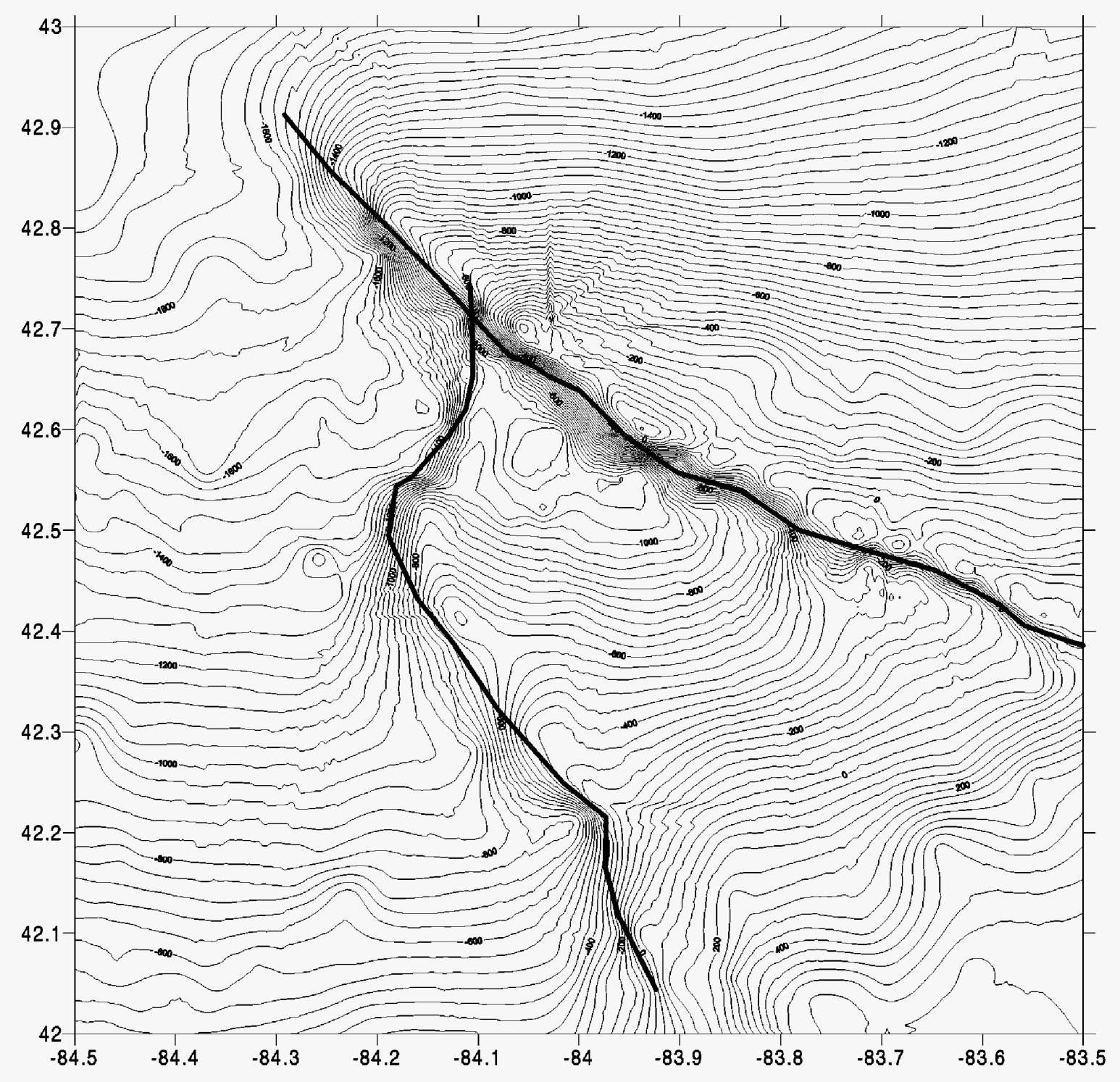

\section{HOWELL ANTICLINE \& LUCAS-MONROE STRUCTURE MAP TOP OF DUNDEE FORMATION $\mathrm{Cl}=10 \mathrm{FT}$.}

Figure 5. Howell Anticline Fault and Lucas-Monroe faults mapper from Dundee formation top picks. 


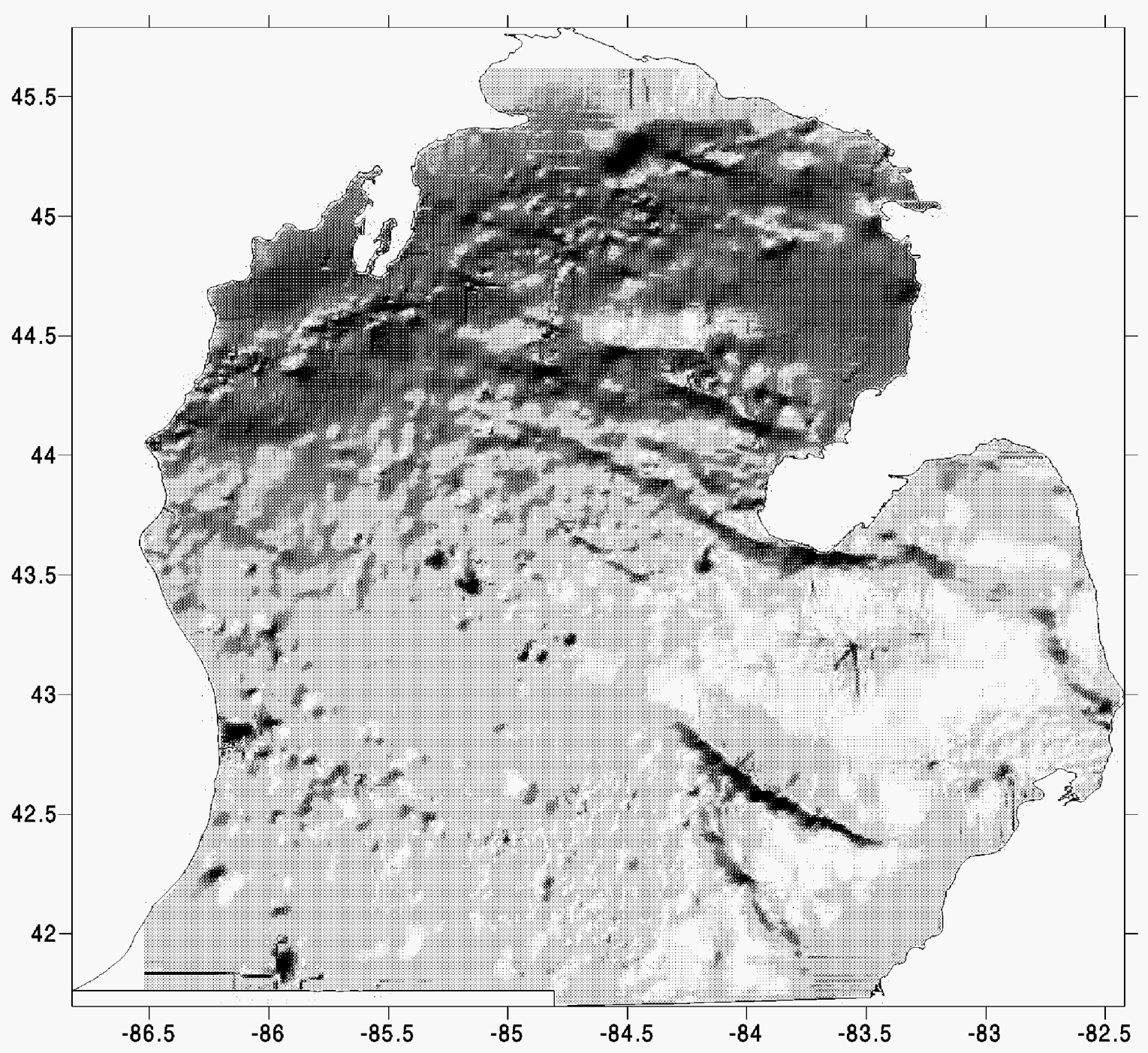

Figure 6. Surface relief map of Michigan based on the gridded tops data for the Dundee Formation. 


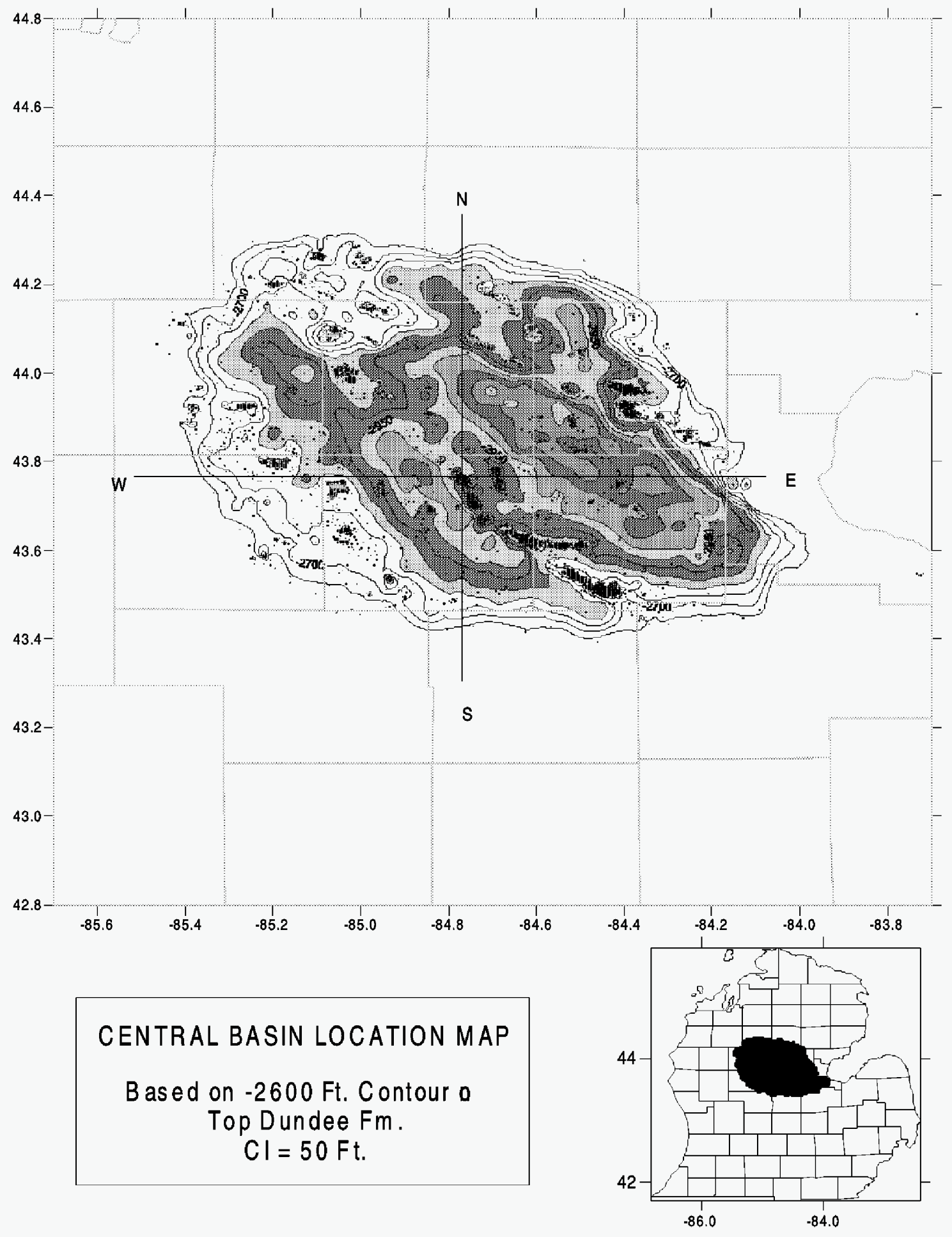

Figure 7. Map showing location and outline of Central Michigan Basin (CMB). Contours represent structure on top of Dundee Formation. 

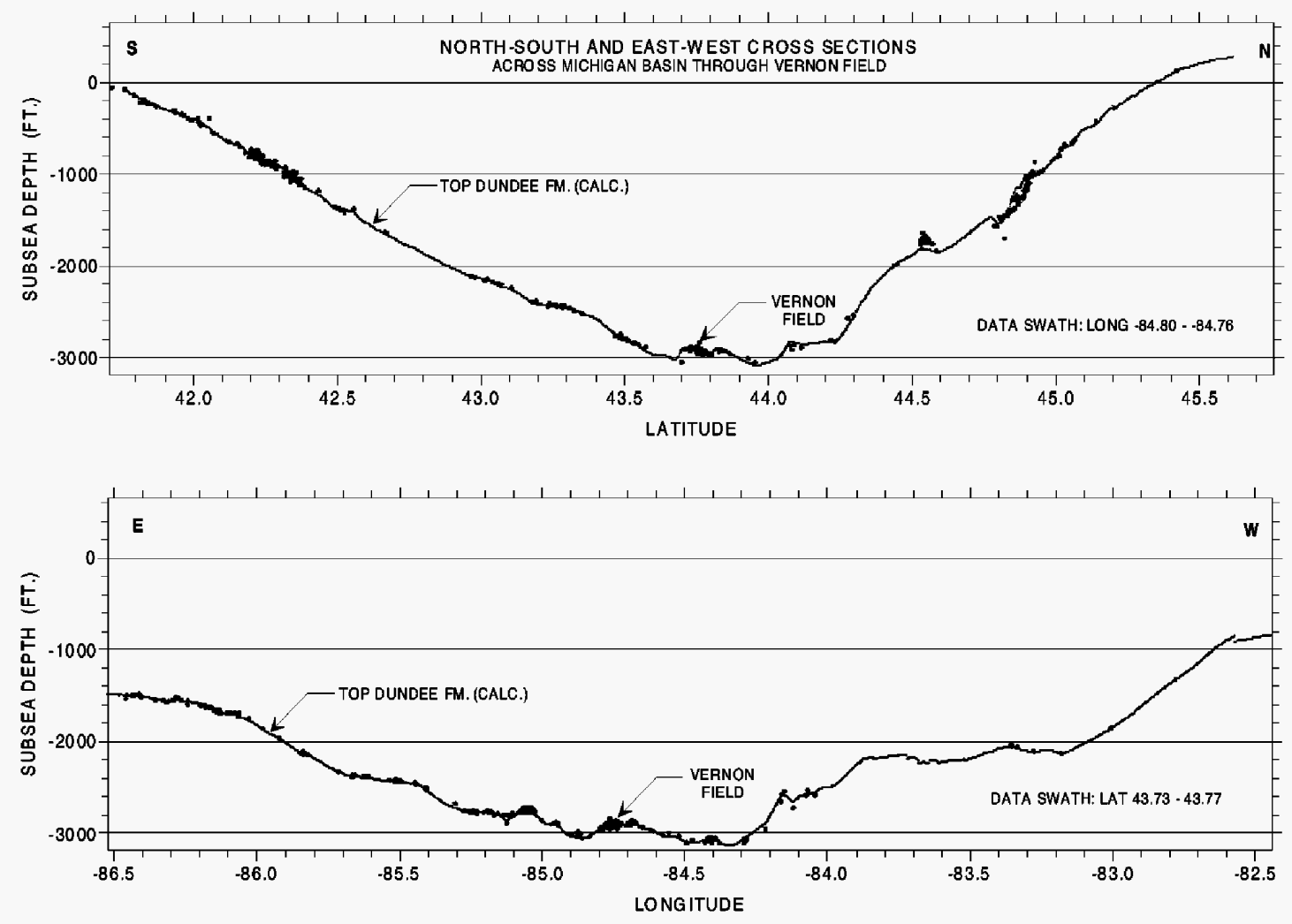

Figure 8. East-West and North-South cross-section across Michigan Basin. Line is calculated from grid of Dundee Formation top data. Points are top picks for Dundee Formation. 

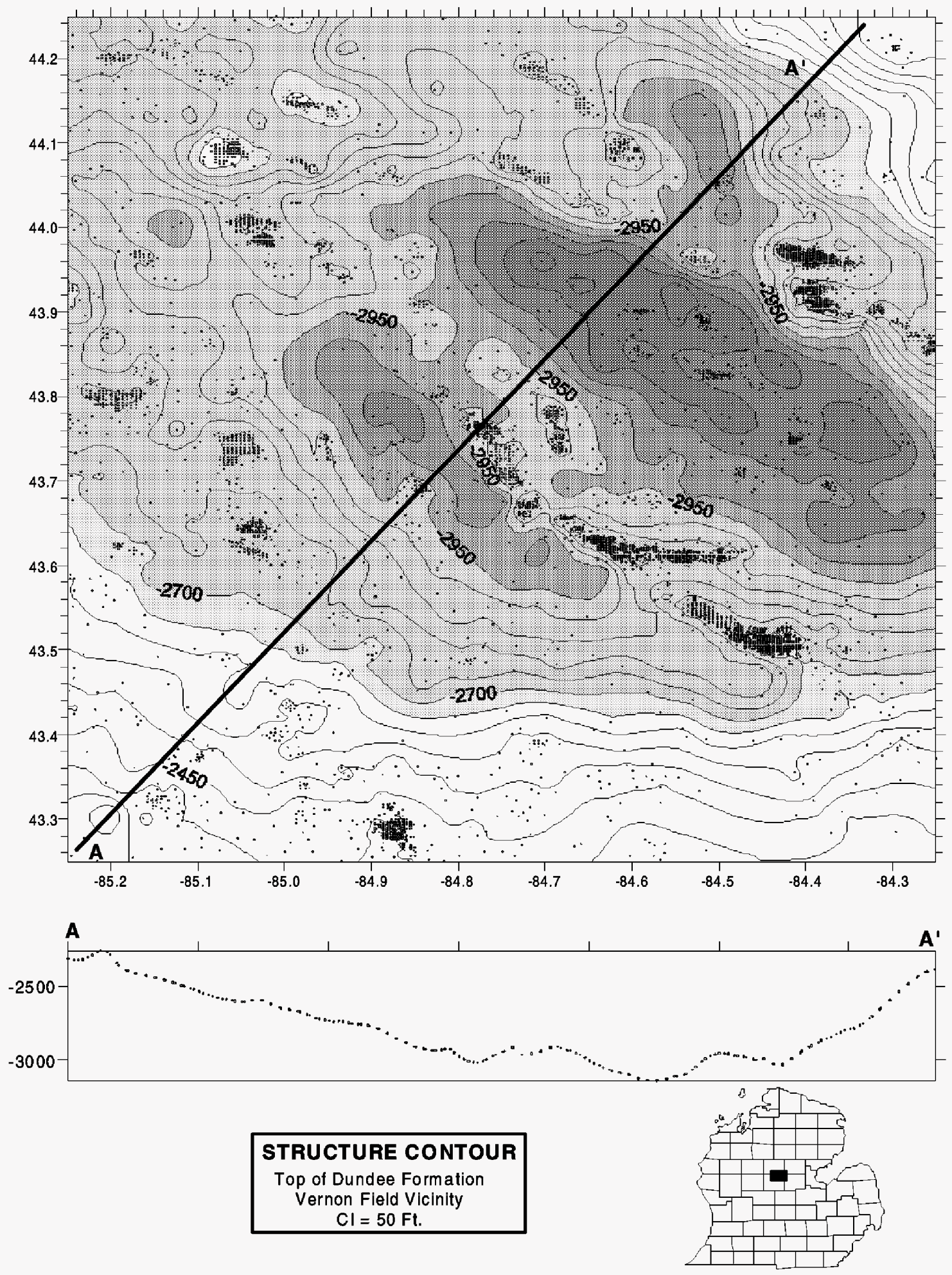

Figure 9. Cross-section across Michigan Basin in vicinityof Vernon Field. Curve represents structure on top of Dundee Formation. 

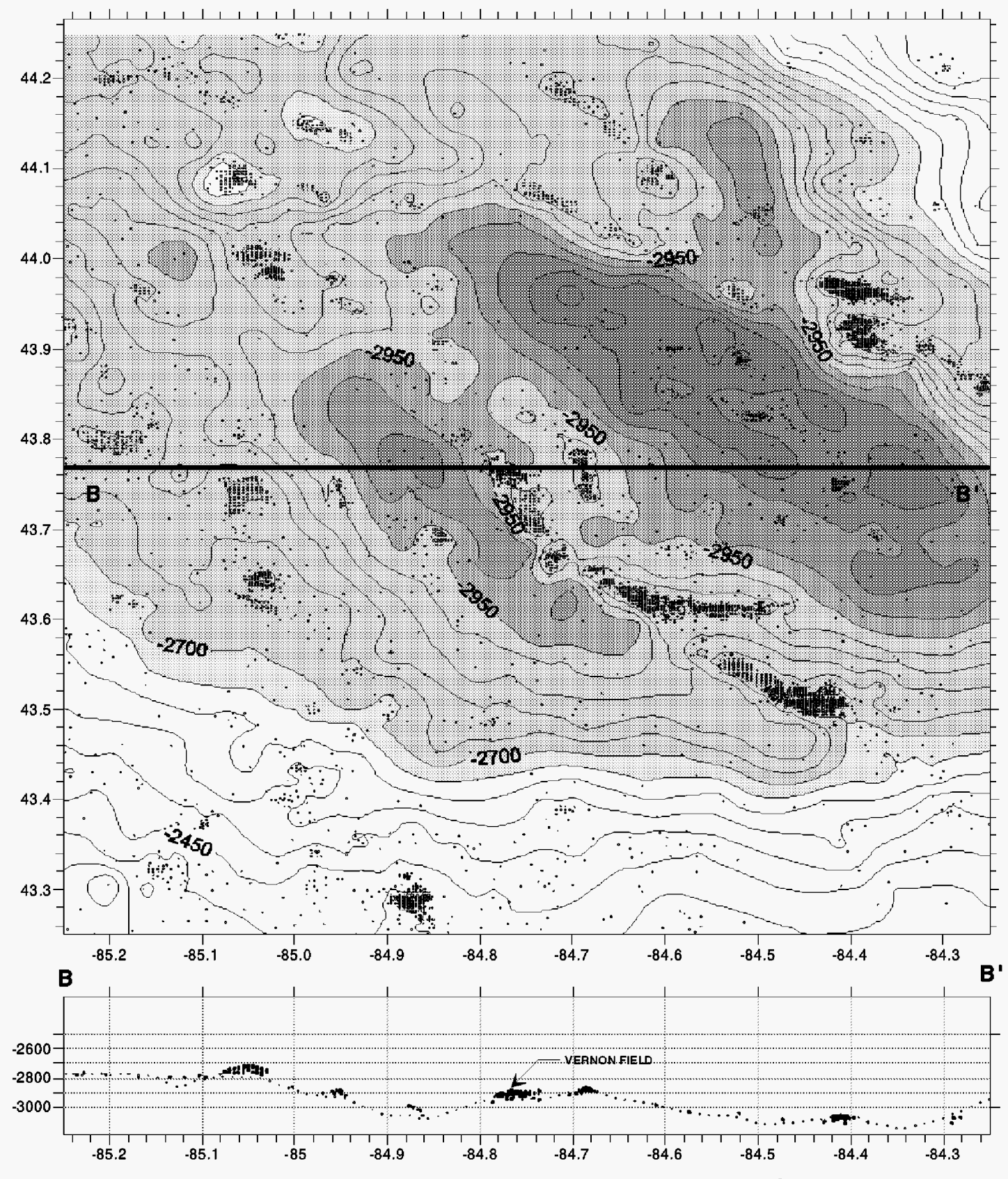

STRUCTURE CONTOUR

Top of Dundee Formation Vernon Field Vicinity $\mathrm{Cl}=50 \mathrm{Ft}$.

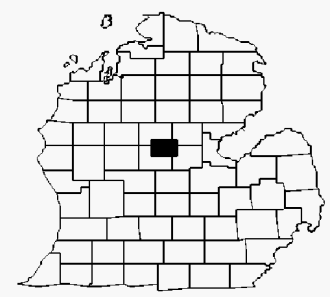

Figure 10. Cross-section across Michigan Basin in vicinityof Vernon Field at latitude 43.76. Curve represents structure on top of Dundee Formation. 


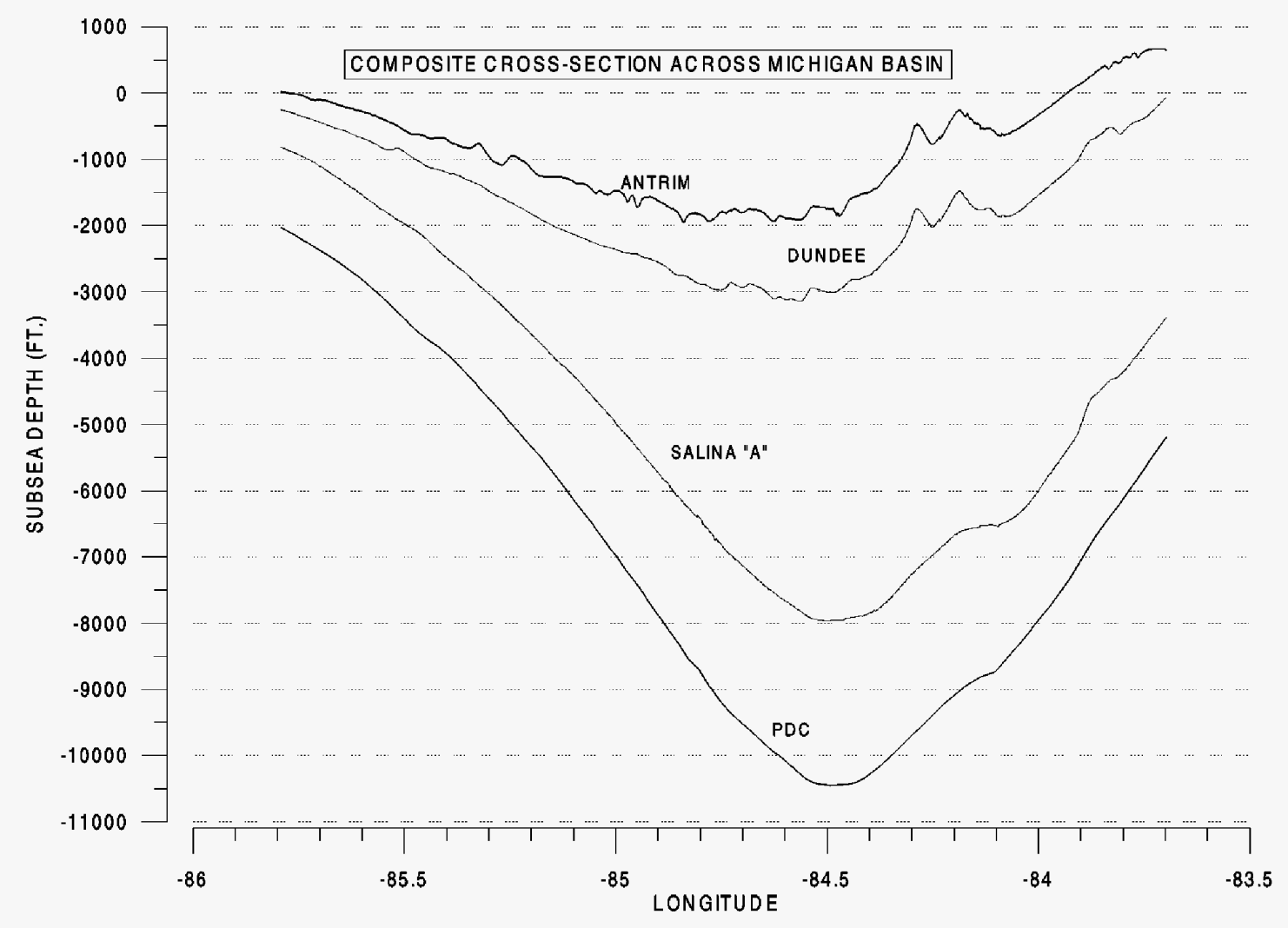

Figure 11. Composite cross section across Michigan Basin at latitude 43.76 for Antrim, Dundee, Salina "A" and Prairie du Chien Formations. 


\section{TABLES}


Table 1. List of Project Fields

\begin{tabular}{|c|c|c|c|}
\hline \multicolumn{4}{|c|}{ MICHIGAN BASIN } \\
\hline 1 & AKRON & 51 & LEROY \\
\hline 2 & ALBION-SCIPIO & 52 & LIME LAKE \\
\hline 3 & BEAR LAKE 22 & 53 & LYON 34 \\
\hline 4 & BELLE RIVER MILLS & 54 & MANISTEE 24 \\
\hline 5 & BELLY ACHERS & 55 & MCBAIN \\
\hline 6 & BLUE LAKE 18 & 56 & NEW LOTHRUP \\
\hline 7 & BROOMFIELD & 57 & NORTH ADAMS \\
\hline 8 & BURDELL & 58 & NORTH CHESTER 18 \\
\hline 9 & CALVIN 28 & 59 & NORTHVILLE \\
\hline 10 & CAPAC & 60 & NORWICH \\
\hline 11 & CAT CREEK & 61 & OIL SPRINGS POOL \\
\hline 12 & CATO & 62 & ONONDAGA 21A \\
\hline 13 & CEDAR & 63 & OVERISEL \\
\hline 14 & CHARLTON 19 PROJECT & 64 & PEACOCK \\
\hline 15 & CHATHAM A POOL & 65 & PENNFIELD 35 \\
\hline 16 & CHESANING 20 & 66 & PETERS \\
\hline 17 & CLAYBANKS 2 & 67 & PETROLIA EAST POOL \\
\hline 18 & CLAYTON & 68 & PORTER \\
\hline 19 & COLDWATER & 69 & PROSPER \\
\hline 20 & COLUMBUS & 70 & PROSPER SOUTH \\
\hline 21 & CRANBERRY LAKE & 71 & RAY \\
\hline 22 & CRANBERRY LAKE EAST & 72 & REDDING \\
\hline 23 & CRYSTAL & 73 & REED CITY \\
\hline 24 & CURRIE & 74 & REYNOLDS \\
\hline 25 & DEEP RIVER & 75 & RIVERSIDE \\
\hline 26 & DEERFIELD & 76 & ROSE CITY \\
\hline 27 & DOUGLASS & 77 & ROSEBUSH \\
\hline 28 & EATON RAPIDS 7 & 78 & SALEM \\
\hline
\end{tabular}




\begin{tabular}{|c|c|c|c|}
\hline 29 & ENSLEY & 79 & SAUBLE \\
\hline 30 & ENTERPRISE & 80 & SHAVER \\
\hline 31 & EVART & 81 & SHERMAN \\
\hline 32 & FALMOUTH & 82 & SIX LAKES \\
\hline 33 & FLETCHER POND & 83 & SKEELS \\
\hline 34 & FORK & 84 & SOUTH BUCKEYE \\
\hline 35 & FOWLERVILLE & 85 & SOUTH BUCKEYE \\
\hline 36 & FREEMAN & 86 & SOUTH CHESTER 21 \\
\hline 37 & GILMORE & 87 & SOUTH VIENNA 30 \\
\hline 38 & GOODWELL & 88 & STONEY LAKE \\
\hline 39 & HANDY 27 & 89 & STONEY POINT \\
\hline 40 & HARDWOOD POINT & 90 & SYLVAN \\
\hline 41 & HARDY DAM & 91 & UNADILLA 2 \\
\hline 42 & HEADQUARTERS & 92 & VERNON \\
\hline 43 & HILLMAN POOL & 93 & WAYLAND \\
\hline 44 & $10 S C O 20$ & 94 & WEST BRANCH \\
\hline 45 & IOSCO 24 & 95 & WHITE OAK 15 \\
\hline 46 & ISABELLA & 96 & WILLIAMS \\
\hline 47 & KAWKAWLIN & 97 & WINTERFIELD \\
\hline 48 & KIMBALL-COLLINVILLE POOL & 98 & WISE \\
\hline 49 & LAKE GEORGE & 99 & WOODVILLE \\
\hline 50 & LEATON & $\begin{array}{l}10 \\
0\end{array}$ & \\
\hline
\end{tabular}


Table 2. Formations with Largest Number of Top Picks in the Michigan Basin

\begin{tabular}{|c|c|c|c|c|c|c|}
\hline $\begin{array}{l}\text { Formation } \\
\text { Code }\end{array}$ & Formation Name & $\begin{array}{l}\text { Aangstro } \\
\mathrm{m}\end{array}$ & DNR & MTU & Total & w/o Dups \\
\hline 701GCDF & Base of Glacial Drift & 38,720 & 23,870 & 1,408 & 63,998 & 45,623 \\
\hline 319ANRM & Antrim Shale & 32,599 & 22,703 & 818 & 56,120 & 38,690 \\
\hline 302TRVR & Traverse Formation & 27,841 & 21,842 & 983 & 50,666 & 35,991 \\
\hline 302TRVRL & Traverse Limestone & 29,599 & 17,979 & 760 & 48,338 & 35,759 \\
\hline 351CLDR & Coldwater Limestone & 28,699 & 15,785 & 1,016 & 45,500 & 32,760 \\
\hline 302DNDE & Dundee & 23,539 & 14,791 & 1,500 & 39,830 & 26,114 \\
\hline 351SNBR & Sunbury & 19,215 & 13,609 & 613 & 33,437 & 23,168 \\
\hline 352MRLL & Marshall Sandstone & 17,594 & 6,495 & 1,070 & 25,159 & 18,481 \\
\hline 351CLDRR & Coldwater Redrock & 15,443 & 4,010 & 264 & 19,717 & 17,836 \\
\hline 351BERE & Berea & 16,705 & 5,953 & 386 & 23,044 & 17,610 \\
\hline 302DRRV & Detroit River & 14,271 & 7,409 & 83 & 21,763 & 15,750 \\
\hline 319ELSR & Ellsworth Shale & 11,401 & 7,230 & 153 & 18,784 & 14,736 \\
\hline 302BELL & Bell Shale & 11,225 & 8,513 & 490 & 20,228 & 13,441 \\
\hline 253SLGU & Salina G Unit & 11,052 & 9,054 & 67 & 20,173 & 13,230 \\
\hline 253SLA2 & A2 Carbonate & 10,452 & 9,294 & 100 & 19,846 & 12,772 \\
\hline 252NGRNB & Brown Niagaran & 10,367 & 9,103 & 11 & 19,481 & 12,710 \\
\hline 253BSIL & Bass Island & 10,361 & 8,760 & 74 & 19,195 & 12,498 \\
\hline 353MCGN & Michigan & 10,294 & 3,783 & 950 & 15,027 & 11,757 \\
\hline 403SGNW & Saginaw & 10,413 & 3,497 & 1,339 & 15,249 & 11,675 \\
\hline 302BBLC & Bois Blanc & 9,155 & 7,984 & 72 & 17,211 & 11,343 \\
\hline 253SLCU & Saline C Unit & 8,965 & 8,533 & 80 & 17,578 & 11,249 \\
\hline 253SLBUS & Salina B Evaporite/Salt & 8,935 & 7,533 & 103 & 16,571 & 11,024 \\
\hline 253SLA2E & A2 Evaporite/Salt & 8,433 & 8,221 & 88 & 16,742 & 10,633 \\
\hline 253SLA1 & A1 Carbonate & 8,402 & 8,287 & 84 & 16,773 & 10,613 \\
\hline 252NGRNG & Gray Niagaran & 7,574 & 6,282 & 3 & 13,859 & 9,380 \\
\hline 253SLEU & Salina E Unit & 5,723 & 7,822 & 72 & 13,617 & 9,290 \\
\hline 353STRY & Stray Sandstone & 8,123 & 2,156 & 1,409 & 11,688 & 8,584 \\
\hline 319BDFD & Bedford Shale & 5,893 & 3,732 & 66 & 9,691 & 7,445 \\
\hline 253SLBU & Salina B Unit & 2,936 & 5,946 & 4 & 8,886 & 7,208 \\
\hline 302AMBG & Amherstburg & 4,773 & 5,929 & 69 & 10,771 & 7,179 \\
\hline
\end{tabular}




\begin{tabular}{|l|l|l|l|l|l|l|}
\hline 353BRLM & Brown Limestone & 6,591 & 1,443 & 899 & 8,933 & 6,936 \\
\hline 253SLDU & Salina D Unit & 6,917 & & 3 & 6,920 & 6,917 \\
\hline 253SLDUS & Salina D Evaporite/Salt & & 6,598 & 48 & 6,646 & 6,615 \\
\hline 353BPRT & Bayport Limestone & 5,853 & 1,882 & 832 & 8,567 & 6,548 \\
\hline 253SLA1E & A1 Evaporite/Salt & 5,214 & 4,769 & 74 & 10,057 & 6,465 \\
\hline 253SLFU & Salina F Unit & 3,301 & 3,809 & 13 & 7,123 & 6,082 \\
\hline BRBD & Berea-Bedford & & 5,483 & & 5,483 & 5,483 \\
\hline 319ANRMD & Dark Antrim & 1,469 & 4,897 & 6 & 6,372 & 5,430 \\
\hline 352MRLLR & Marshall Redrock & 4,972 & & 273 & 5,245 & 5,091 \\
\hline 302SYLN & Sylvania & 4,394 & 1,821 & 45 & 6,260 & 4,945 \\
\hline 252CLNN & Clinton Shale & 4,191 & 2,436 & 84 & 6,711 & 4,618 \\
\hline 403PARM & Parma Sandstone & 3,497 & 932 & 511 & 4,940 & 3,921 \\
\hline 302RCFD & Richfield Zone & 3,416 & 1,727 & 41 & 5,184 & 3,830 \\
\hline 202TRNN & Trenton & 3,395 & 2,026 & 69 & 5,490 & 3,715 \\
\hline 203CNCN & Cincinnatian & 3,199 & 1,869 & 85 & 5,153 & 3,538 \\
\hline 559JRSCR & Red Beds & 2,924 & 425 & 715 & 4,064 & 3,245 \\
\hline 302DRRVA & Detroit River Anhydrite & & 2,999 & 58 & 3,057 & 3,040 \\
\hline 202BKRV & Black River & 2,696 & 1,737 & 69 & 4,502 & 3,016 \\
\hline 203UTIC & Utica Shale & 2,688 & 1,173 & 76 & 3,937 & 2,948 \\
\hline 353TPGP & Triple Gypsum & 1,924 & 1,330 & 323 & 3,577 & 2,352 \\
\hline
\end{tabular}


